DOI: $10.2478 / \mathrm{rrlm}-2014-0009$

\title{
Venous thromboembolism caused by testosterone abuse in a young man with previously undiagnosed genetic thrombophilia
}

\section{Trombembolism venos cauzat de abuzul de testosteron la un bărbat tânăr cu trombofilie ereditară nediagnosticată anterior}

\author{
Voichiţa Ileana Sîrbu ${ }^{1,2}$, Irina Pintilie ${ }^{2}$, Mihaela M Oprişs, \\ 1. Medical Clinic V, University of Medicine and Pharmacy, Târgu Mureş, Romania \\ 2. Emergency Institute for Cardiovascular Diseases and Transplantation, Cardiology Clinic, \\ Târgu Mureş, Romania
}

\begin{abstract}
Venous thromboembolism (VTE) is a multifactorial disease; age, a prior history of deep vein thrombosis, cancer, surgery, obesity, prolonged immobility, pregnancy, oral contraceptive agents, thrombophilia, have been identified as major risk factors. Thrombophilia is a heritable or acquired prothrombotic state that increases the tendency to venous thromboembolism. The use of anabolic steroids is strongly linked to venous thromboembolism, due to their role in thrombus formation. We present a case of a venous thromboembolism in a 26-year old male who had undergone a testosterone abuse and had a previously undiagnosed genetic thrombophilia, with discussion upon literature regarding the heritable thrombophilia and prothrombotic effects of testosterone.
\end{abstract}

Keywords: venous thromboembolism, thrombophilia, testosterone.

\section{Rezumat}

Trombembolismul venos este o boală multifactorială; vârsta, antecedentele de tromboză venoasă profundă, cancerul, intervenţiile chirurgicale, obezitatea, imobilizarea prelungită, sarcina, consumul de anticoncepţionale, trombofilia, au fost identificaţi ca factori de risc majori. Trombofilia este un status protrombotic moştenit sau dobăndit care creşte tendinţa la trombembolism venos. Folosirea steroizilor anabolizanţi este strâns legată de trombembolismul venos datorită rolului lor protrombotic. In lucrarea de faţă prezentăm un caz de trombembolism venos la un bărbat de 26 ani care a folosit în mod abuziv testosteron injectabil şi avea o trombofilie genetică nediagnosticată anterior, cu discuţii din literatura de specialitate referitoare la trombofilia ereditară şi efectele protrombotice ale testosteronului.

Cuvinte cheie: trombembolism venos, trombofilie, testosteron

Received: 21 ${ }^{\text {st }}$ August 2013; Accepted: $8^{\text {th }}$ February 2014; Published: $10^{\text {th }}$ March 2014.

*Corresponding author: Voichiţa I. Sîrbu, University of Medicine and Pharmacy Târgu Mureş, phone: 0040726280668,e-mail:voichhi@yahoo.com 


\section{Introduction}

Pulmonary embolism and deep vein thrombosis are two diseases that are closely linked together. Thrombi that are formed in the deep calf veins are carried off in the pulmonary circulation, where they cause blockage of the pulmonary arteries (1). Age, a prior history of deep vein thrombosis, cancer, surgery, obesity, prolonged immobility, pregnancy, oral contraceptives use and thrombophilia have been identified as major risk factors for venous thromboembolism (term that includes together deep vein thrombosis and pulmonary embolism). Thrombophilia is a heritable or acquired prothrombotic state that increases the tendency for venous thromboembolism (2). Anabolic steroids use and abuse in athletes is also strongly linked to cardiovascular events, such as myocardial infarction, stroke or pulmonary embolism, due to their role in thrombus formation (3).

\section{Case presentation}

A 26-year old man presents at the emergency unit after experiencing pain for 24 hours, stiffness and swelling of his right thigh and calf. He admitted having a mild breathlessness on exertion, while he was exercising at the gym, but he had no dyspnea at rest. The physical examination revealed a warm, painful and swollen right thigh, with collateral circulation, but no other specific findings. Blood pressure $(120 / 80 \mathrm{mmHg})$ and respiratory rate (17 breaths per minute) were normal, with a peripheral arterial saturation of $99 \%$.

The electrocardiography showed a sinus rhythm at a ventricular rate of $80 \mathrm{bpm}$, without any signs of right ventricular overload, the pulmonary radiography was normal and the blood results revealed highly-positive D-dimers and normal values for cardiac troponin I and brain natriuretic peptide. Ultrasonography of the right leg confirmed the presence of a thrombus in the right ilio-femoral vein and inferior vena cava. A computer tomography angiogram of the pulmonary arteries showed emboli in both inferior lobar arteries, without any pleural effusion or pulmonary parenchymal abnormalities (Figure 1). The echocardiogram performed showed no signs of right ventricle enlargement or pulmonary hypertension.

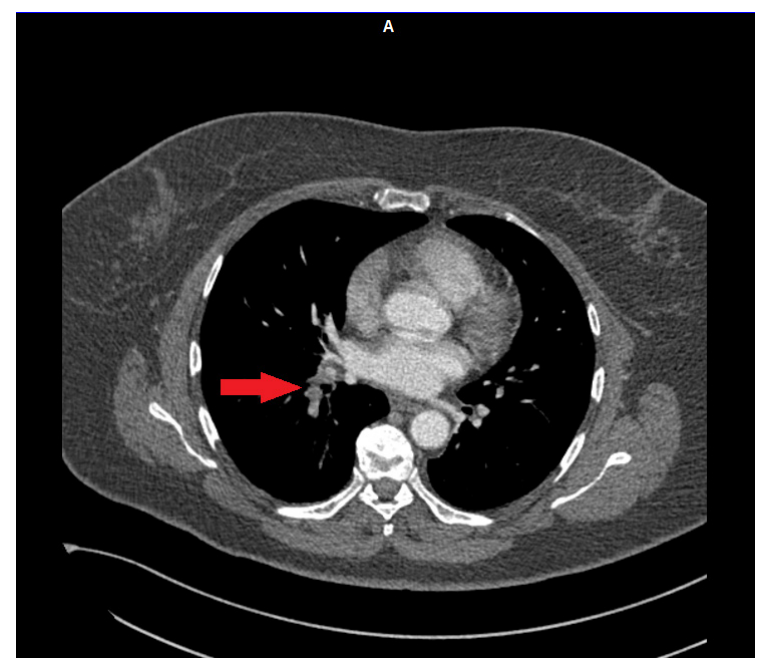

Figure 1. CT angiogram showed emboli in pulmonary artery.

The patient was a smoker and denied any history of previous personal thrombotic events, malignant disease, surgery or immobilization, but reported thrombotic family history, a 40 -year-old aunt with deep vein thrombosis. On further questioning, he admitted being a frequent gym visitor and having used intramuscular testosterone injections, in high doses, $1250 \mathrm{mg} /$ week, four consecutive weeks, without any medical prescription. Blood results revealed a high level of testosterone of $12.7 \mathrm{ng} / \mathrm{ml}, 10$ days after the last dose (normal values $2.8-8 \mathrm{ng} / \mathrm{ml}$ ) and a normal estradiol level of $38.52 \mathrm{pg} / \mathrm{ml}$ (normal values $7.6-42.6 \mathrm{pg} / \mathrm{ml}$ ), 18 days after the last testosterone dose.

Given the fact that protein $\mathrm{C}$, protein $\mathrm{S}$, homocysteine and antithrombin deficiencies should be tested after discontinuation of anticoagulant 
therapy, further genetic investigations were conducted. Genotyping of common thrombophilia-related polymorphisms (factor V Leiden G1691A, factor II G20210A, Methylenetetrahydrofolate reductase MTHFR C667T and MTHFR A1298C) was performed on a sample of whole venous blood collected on vacutainer tube with K3 ethylenediaminetetraacetic acid (EDTA). Genomic deoxyribonucleic acid (DNA) was purified from $200 \mu \mathrm{L}$ of sample, using a silica membrane spin column method. Afterwards, the presence of polymorphisms was assessed by real-time polymerase chain reaction, using fluorescence resonance energy transfer (FRET) probes. Tests for factor V Leiden G1691A, factor II G20210A and MTHFR C667T gene mutations were negative, but the patient tested positive for the heterozygous mutation of MTHFR A1298C gene.

The patient was given anticoagulation therapy consisting of low-molecular weight heparin (enoxaparine) for 7 consecutive days at a dose of $1 \mathrm{mg} / \mathrm{kg}$ twice daily and concomitantly antivitamine $\mathrm{K}$ (acenocoumarol) aiming to achieve a therapeutic range INR (between 2 and 3). He was discharged in good clinical condition with oral anticoagulant treatment. We recommended identifying congenital risk of thrombosis in first degree relatives, especially in the patient's aunt with previous deep vein thrombosis (for secondary antithrombotic prophylaxis) and his young sister who used oral contraceptives (for primary antithrombotic prophylaxis).

\section{Discussions}

Venous thromboembolism (VTE) is a multifactorial disease and patients suffering from VTE have been sometimes diagnosed with thrombophilia. Acquired thrombophilia is most commonly caused by antiphospholipid syndrome (lupus anticoagulant or antibodies against cardiolipin or $\beta 2$-glycoprotein I). Her- itable or congenital thrombophilia is caused by a deficiency of natural anticoagulants (protein $\mathrm{C}$, protein $\mathrm{S}$, antithrombin III) or by a genetic mutation of factor V Leiden - G1691A, factor II - prothrombin G20210A or Methylenetetrahydrofolate reductase MTHFR (C677T and A1298C) (2). The impact of genetic mutations on the risk of thrombosis is not yet fully known and current research findings are sometimes discordant. In healthy Caucasian populations without thrombotic events, a genetic mutation of factor V Leiden - G1691A was identified in a percentage ranging between 3-5\% and was associated with an increase in basal D-dimers and a mild hypercoagulable state. Genetic mutation of factor II - prothrombin G20210A was identified in $3 \%$ of healthy Caucasians with no hypercoagulable state associated (4). The MTHFR gene is less studied both in healthy people as well as in patients with different diseases. It is involved in the folate metabolism and is closely linked to elevated plasma levels of homocysteine, which is known to cause thrombotic events. The protein encoded by this gene catalyzes the conversion of 5,10-methylenetetrahydrofolate to 5-methyltetrahydrofolate, a co-substrate for homocysteine remethylation to methionine. Genetic variations in this gene influence susceptibility to occlusive vascular disease, neural tube defects, colon cancer and acute leukemia (5). Case reports and smaller trials have shown that MTHFR C677T and MTHFR A1289C polymorphism are connected with total homocysteine plasma levels in patients with occlusive artery disease and deep venous thrombosis $(6,7)$. A recent large meta-analysis involving over 11,000 cases and 21,000 controls confirmed a moderate risk (weaker than previously thought) for venous thromboembolism of genetic mutations of factor V Leiden - G1691A and factor II - prothrombin G20210A, but no effect was found for C677T MTHFR. The risk is increased if there are two genetic mutations, in people under 45 years or 
in women taking oral contraceptives (8). Also, according to the American College of Medical Genetics Practice Guidelines, MTHFR polymorphism testing should not be ordered as part of a routine evaluation for thrombophilia (9).

A review of the Guidelines from Scientific Societies and Working Groups shows a higher risk gradient for VTE in patients with deficiency of protein $\mathrm{C}$, protein $\mathrm{S}$, antithrombin III, multiple or homozygous abnormalities of factor $\mathrm{V}$ Leiden - G1691A or factor II - prothrombin G20210A and a moderate risk gradient for VTE in patients with heterozygous abnormalities of factor V Leiden - G1691A or factor II - prothrombin G20210A. VTE risk is highly dependent on family history of VTE (10).

Testosterone is the anabolic-androgenic steroid hormone used extensively by bodybuilders, without prescription, for increasing muscle mass and strength. On websites that sell such preparations, doses used for intramuscular injections are between 250 milligrams and 1000 milligrams/week, using lower doses for beginners or those with body weight under 70 kilograms. In our case, the patient had 70 kilograms and used high doses of intramuscular testosterone injections, $1250 \mathrm{mg} /$ week, for four consecutive weeks. Patients who persistently abuse high doses of anabolic steroids are at risk of death from premature heart disease (hypertension, coronary artery disease), stroke or cancer, especially prostate cancer. Currently, the exact mechanism of cardiovascular adverse effects is not entirely known; anabolic steroids have atherogenic and thrombogenic effects, they produce endothelial dysfunction and quantitative changes in the levels of anticoagulant and procoagulant factors (increased levels of homocystein and clotting factors) (11). Prospective cohort or case-control studies showed no clear association between endogenous testosterone and VTE risk (12). It is supposed that exogenous testosterone is aromatized to estradiol (E2) and its effect causes a hypercoagulable state called by some authors, E2-induced thrombophilia (13). In our case, blood results revealed a high level of testosterone at the 10th day, after the last injection but a normal estradiol level performed only at the $18^{\text {th }}$ day after the last dose (when the blood tests were possible).

Previously undiagnosed genetic thrombophilia has been discovered in patients with thrombotic events undergoing exogenous testosterone treatment. The mechanism is supposed to consist of E2-induced thrombophilia overlapping existing familial thrombophilia (14). It is certain that VTE in this previously healthy young man is linked to injectable testosterone abuse, to which there is a clear correlation in time. In this case only MTHFR A1298C heterozygosity was found to be a genetic condition. Even if current evidence on the relationship between MTHFR polymorphism and VTE are inconsistent, we assume that in this case this genetic mutation correlated with family history and testosterone abuse has contributed to the onset of VTE.

Subsequent use of anabolic hormones without medical indication was prohibited in this patient. We recommended anticoagulation treatment with antivitamin $\mathrm{K}$ for 3 months, then the opportunity to continue anticoagulant therapy will be reevaluated, based on the presence or the absence of the following higher long-term risk factors: residual thrombosis in the proximal veins, antiphospholipid syndrome, deficit of protein $\mathrm{C}$, protein $\mathrm{S}$, or antithrombin III, the D-dimer level $(10,15)$.

Most guidelines recommend identifying inherited risk in first-degree relatives of patients with VTE and natural anticoagulants deficiency or multiple genetic abnormalities (10). Considering the family history, we also recommended identifying inherited risk of thrombosis in the family's first degree relatives, especially in the patient's aunt with previously deep vein thrombosis (for secondary antithrombotic prophylax- 
is) and his young sister who used oral contraceptives (for primary antithrombotic prophylaxis). Identification of thrombophilia in these relatives can prevent VTE by administering prophylactic anticoagulation during risk situations (10).

\section{Conclusions}

In this report we have presented the case of venous thromboembolism caused by testosterone abuse in a young man with previously undiagnosed genetic thrombophilia. It is recommended that young patients with a family history of thrombotic events, who use hormonal therapy, oral contraceptives or anabolic steroids, are tested for the exclusion of heritable thrombophilia.

\section{Conflicts of interest: None declared.}

\author{
Abbreviations \\ $\mathrm{VTE}=$ venous thromboembolism \\ DNA $=$ deoxyribonucleic acid \\ FRET $=$ fluorescence resonance energy trans- \\ fer \\ $\mathrm{MTHRF}=$ Methylenetetrahydrofolate reduc- \\ tase
}

\section{References}

1. Tapson VF. Acute pulmonary embolism. N Engl J Med. 2008 Mar 6;358(10):1037-52. DOI: 10.1056/NEJM$\mathrm{ra} 072753$

2. National Clinical Guideline Centre (UK). Venous Thromboembolic Diseases: The Management of Venous Thromboembolic Diseases and the Role of Thrombophilia Testing [Internet]. London: Royal College of Physicians (UK); 2012 Jun. http://www.ncbi. nlm.nih.gov/books/NBK132796/

3. Dickerman RD, McConathy WJ, Schaller F, Zachariah NY. Cardiovascular complications and anabolic steroids. Eur Heart J. 1996 Dec;17(12):1912.

4. Mazoyer E, Ripoll L, Gueguen R, Tiret L, Collet JP, dit Sollier CB, et al.; FITENAT Study Group. Prevalence of factor V Leiden and prothrombin G20210A mutation in a large French population selected for nonthrombotic history: geographical and age distribution. Blood Coag- ul Fibrinolysis. 2009 Oct;20(7):503-10. DOI: 10.1097/ MBC.0b013e32832f5d7a

5. Bienvenu T, Ankri A, Chadefaux B, Montalescot G, Kamoun P. Elevated total plasma homocysteine, a risk factor for thrombosis. Relation to coagulation and fibrinolytic parameters, Thrombosis Research, 1993 April;70(2):123-25. DOI: 10.1016/00493848(93)90153-F

6. Spiroski I, Kedev S, Antov S, Arsov T, Krstevska M, Dzhekova-Stojkova S, et al. Methylenetetrahydrofolate reductase (MTHFR-677 and MTHFR-1298) genotypes and haplotypes and plasma homocysteine levels in patients with occlusive artery disease and deep venous thrombosis. Acta Biochim Pol. 2008;55(3):587-94. Epub 2008 Sep 18.

7. Quéré I, Chassé JF, Dupuy E, Bellet E, Molho-Sabatier P, Tobelem G, et al. Homocysteine, 5,10-methylenetetrahydrofolate reductase and deep venous thrombosis. Survey of 120 patients in internal medicine. Rev Med Interne. 1998 Jan;19(1):29-33. DOI: 10.1016/S02488663(97)83696-X

8. Simone B, Stefano VD, Leoncini E, Zacho J, Martinelli I, Emmerich J, et al. Risk of venous thromboembolism associated with single and combined effects of Factor V Leiden, Prothrombin 20210A and Methylenetethraydrofolate reductase C677T: a meta-analysis involving over 11,000 cases and 21,000 controls. Eur J Epidemiol. 2013 Aug 1;28(8):621-47. DOI: 10.1007/s10654013-9825-8

9. Hickey SE, Curry CJ, Toriello HV. ACMG Practice Guideline: lack of evidence for MTHFR polymorphism testing. Genet Med. 2013 Feb;15(2):153-6. DOI: 10.1038/gim.2012.165

10. De Stefano V, Rossi E. Testing for inherited thrombophilia and consequences for antithrombotic prophylaxis in patients with venous thromboembolism and their relatives. A review of the Guidelines from Scientific Societies and Working Groups. Thromb Haemost. 2013 Oct;110(4):697-705. DOI: 10.1160/TH13-01-0011

11. Ilhan E, Demirci D, Güvenç TS, Calık AN. Acute myocardial infarction and renal infarction in a bodybuilder using anabolic steroids. Turk Kardiyol Dern Ars. 2010 Jun;38(4):275-8.

12. Choi BG, McLaughlin MA. Why men's hearts break: cardiovascular effects of sex steroids. Endocrinol Metab Clin North Am. 2007 Jun;36(2):365-77. DOI: 10.1016/j.ecl.2007.03.011

13. Glueck CJ, Goldenberg N, Budhani S, Lotner D, Abuchaibe C, Gowda M.et al. Thrombotic events after starting exogenous testosterone in men with previously undiagnosed familial thrombophilia. Transl Res. 2011 Oct;158(4):225-34. DOI: 10.1016/j.trs1.2011.06.003

14. Glueck CJ, Richardson-Royer C, Schultz R, Burger T, Labitue F, Riaz MK, et al. Testosterone, Thrombophil- 
ia, and Thrombosis. Clin Appl Thromb Hemost. 2014 Jan;20(1):22-30. DOI: 10.1177/1076029613485154

15. Torbicki A, Perrier A, Konstantinides S, Agnelli G, Galiè N, Pruszczyk P.et al. ESC Committee for Practice Guidelines (CPG). Guidelines on the diagnosis and management of acute pulmonary embolism: the Task Force for the Diagnosis and Management of Acute Pulmonary Embolism of the European Society of Cardiology (ESC). Eur Heart J. 2008 Sep;29(18):2276-315. DOI: $10.1093 /$ eurheartj/ehn310 